\title{
Assessing Strategic Orientation and Mosques Performance
}

\author{
Ahmad Raflis Che Omar ${ }^{1,2}$, Mohd Yahya Mohd Hussin ${ }^{1} \&$ Fidlizan Muhammad ${ }^{1}$ \\ ${ }^{1}$ Faculty of Management and Economics, Universiti Pendidikan Sultan Idris, Malaysia \\ ${ }^{2}$ Faculty of Economics and Management, Universiti Kebangsaan Malaysia, Malaysia \\ Correspondence: Fidlizan Muhammad, Faculty of Management and Economics, Universiti Pendidikan Sultan Idris, \\ Malaysia.E-mail: fidlizan@fpe.upsi.edu.my
}

Received: October 10, 2019

Accepted: November 5, 2019

Online Published: December 23, 2019

doi:10.5430/rwe.v10n5p30

URL: https://doi.org/10.5430/rwe.v10n5p30

\begin{abstract}
Mosque plays important roles as the religious organization among Muslims. Despite a sacred place, there are some other socio-economic roles are carried out by these institution such as the Islamic teaching and learning centre, waqf and zakat (alms) management and hearse management. Nevertheless, currently there are increasing number of economic activities executed by mosque leaders to serve the local Muslims community. This study assesses the relationship between strategic orientation initiatives and mosque's economic performance. The data is gathered through a structured questionnaire that was distributed amongst the mosques management committee leaders in the State of Selangor. The outcomes of path model analysis highlighted two important findings. First, the strategic orientation does exist among mosques management committee leaders. Second, relationship between strategic orientation and mosques non-financial performance is significantly related. The empirical evidence provides important initial exploration on enhancement of strategic orientation theory in the context of religion based organization. Drawing from the findings, we promote strategic choice for future mosque's strategic engagement with certain types of valuable community based economic activities.
\end{abstract}

Keywords: strategic orientation, mosque, performance, economy

\section{Introduction}

Strategic orientation (SO) is gaining more attention in determining the performance and competitive advantage of many organizations (Aloulou, 2019). Strategic oriented organization normally embarked with strategic principles of market orientation, technology orientation or entrepreneurial orientation that influence organization activities and behaviours that intended to gain best performance (Basbeth et al., 2019; Chatzoglou et al., 2018). SO substantially influences organization activities, investments and their economic performance by mobilizing their valuable assets, capabilities, technology and skills (Al-Ansaari, Bedder \& Chen, 2015; Gamba, 2017). Further, SO derive the capability of organizations to explore high values business opportunity, innovative initiatives and improving organizational risk-taking propensity (Baba, 2015, Basbeth et al., 2019). Since the strategic management research has normally concentrated on the context of large firms, this study is concentrated in the context of religious based organization, i.e. mosques. It is due to inclination of mosque management committee towards improving their economic involvement by promoting certain social business activities within their vicinity (Omar, Hussin \& Muhammad, 2017). However, we hardly found empirical evidence about the strategic orientation and mosque performance concerning their economics activities.

Mosque is the place for ritual worship, Islamic educational activities and other important strategic roles in Muslims community (Budiman \& Sadewa, 2018). At the time of Prophet Muhammad pbuh, mosque was functioning as the place of Muslims administrative, judiciary and economic centre, community centre, and arranging of war strategies (Razak, 2014). However, over the time mosques are more concentrated on the ritual activities and Islamic education (Sharif, Wahab \& Sarip, 2017; Yasoa et al., 2019). As the public organization, other functions is seemed to be limited to such a passive economics activities related to the tasks of managing public donation, waqf and zakat (alms), maintenance of mosques assets and distribution of public donation to the needy. Surprisingly, there are certain business and economic activities arises amongst mosques in Malaysia as reported by Razak et al., (2014) and Muhammad et al., (2014). 
Previous study reiterates that mosque's management committee leaders should improve their capabilities, commitment and skills towards enhancing active economic activities. Studies by Razak et al., (2014) had revealed that mosque has big amount of funds accumulated from various religion-based sources but inactively invested them into more effective mode of investment rather than investment account and saving account at the local banks. Some other mosque involved with passive economics activities such as assets rental or space rental for other auto-teller machine (ATM), vending machine, massage chairs, and telecommunication tower site (Budiman \& Sadewa, 2018). Consequently, they earned lesser amount of return as compared to other types of investments (Muhammad et al., 2014). However, a review of literature on mosque economic commitment suggests that only few studies did explore the relationships between strategic orientations and mosque economic performance. Therefore, this study investigates the existence of strategic orientation initiatives amongst mosque leaders and its relationship towards the economic performance. By applying a quantitative approach, this study has two specific objectives. First, it aims to contribute to the development of knowledge and theory regarding mosque strategic oriented context. Second, it may offer practical recommendations to mosque management committee in strategic decisions to achieve optimal return from their economic activities involvement.

\section{Literature Review}

Strategic orientation is define as organization decision-making styles, processes, and practices that influence their activities and performance (Aloulou, 2019; Al-Ansaari, Bedder \& Chen, 2015; Sen, Bingol \& Vayvay, 2017). In other related perspectives, Baba (2015) postulates the strategic orientation as the organization's philosophy of how to conduct business which reflecting enhanced values with its environment. The principles are related process in which business and social organization engage with offering new products or new services, risk taking, innovation, and pro-active action in their activities and business process (Basbeth et al., 2019; Miller, 1983). Strategic orientation guides the direction of the social organization to pursue their activities (Storey and Hughes, 2013). Baba (2015) specifically relates the important of strategic orientation in terms of learning orientation measurement on deriving non-profit organization achievement (Sriyana, 2019). Parallel to the ideas of expectancy-value theory, Lumpkin and Dess (1996) proposed that entrepreneurial orientation is the core values of strategic orientation that captures the extent to which organization strives to develop new opportunities (Hussain et al., 2019).

Social organization should create higher competitive advantage on its activities, investment, and performance (Baba, 2015). As such, mosque leaders should strive to improve performance by developing and implementing effective strategies that exploit economic opportunities while capitalizing on available assets and capabilities (Budiman \& Sadewa, 2018). However, not all leaders inculcate to strategies in the same way. Therefore, inclination of top management towards strategic orientation will positively strengthen the social institutions efficiency (Jaafar et al., 2013; Baba, 2015; Omar, Hussin \& Muhammad, 2017). However, past studies are more focusing on strategic orientation among profit-based organizations (Storey \& Hughes, 2013; Al-Ansaari, Bedder \& Chen, 2015; Yadav, Tripathi \& Goel, 2019). Little is known about the existence of strategic orientation among non-profit religion based organization (Omar, Hussin \& Muhammad, 2017; Cossiga, 2018). As these groups of organizations are gradually pursue various economic activities, strategic management and decision-making practices are crucial for their survival (Masood, Tvaronavičienė \& Javaria, 2019).

\section{Methodology}

This study applies quantitative research method by using a set of questionnaires distributed to the top management committee member of mosque in the State of Selangor, Malaysia. The samples are been selected among the mosques located in the top five districts with highest population within the state. The districts understudy was Hulu Langat, Gombak, Petaling, Klang and Sepang with a total number of mosques is 261. Purposive sampling method is used, as the targeted mosques are perceive to execute at least one or two types of economic activities. Prior to the distribution of the questionnaires (by mail), a phone call has been made to the respective respondent to request for their permission and commitment in the study. The list and contact number of the respondent are acquire from the on-line mosques database of the State Religious Department.

The first section of the questionnaire related to mosque and management profile while the second part contained several questions regarding the strategic orientation measurement. The strategic orientation is measure uni-dimensionally by applying three modified constructs proposed by Miller (1983) and Covin and Slevin (1996) risk taking, innovation and pro-activeness of the organization. Each of the questions are measure with a five-point Likert scale. The final section contained the performance indicators of financial and non-financial measurement of the mosque's economic activities as suggested by Rahman, Mastuki and Yusof (2015). The measurement of financial 
performance is based on average revenue from business related activities in three years period. While the non-financial performance was measure by numbers of economic activities being executed for the past three years.

The data were analysis with the SmartPLS 3. The software allows the assessment of validity and reliability of the study effectively. The descriptive analysis covers frequency, mean and outer loadings. Cronbach Alpha test, composite reliability and the average variance extracted were used to validate the data. Hypothesis is measure by the $p$-value.

\section{Results}

Throughout the study, there are 134 questionnaire were returned from the whole 198 questionnaires distributed the respective mosque's leader. Therefore, the response rate is about $67.7 \%$. The respond rate is considered high due to the phone call made prior to the distribution of the survey instrument. Table 1 presents the demographic information about the samples.The highest respons came from mosques in the district of Petaling (30.6\%) and the lowest is from Sepang (7.4\%). In term of size, most of the sample have the congregational capacity of 500 to 1,000 people at one time (30.6\%). This is due to the limited size of land available in Selangor and certain high-developed districts in Selangor where there are small plot size is normally dedicated for mosque development by the state government. At the same time, there are mosques that been upgraded from a small or medium size surau (musolla) with the residential area to become a mosque for the purposes of Jumaat prayer and other related religion activities.

Table 1. Demographic of mosques

\begin{tabular}{llcc}
\hline & & Frequency & Percentage \\
\hline Location & District of Hulu Langat & 28 & 20.9 \\
& District of Petaling & 41 & 30.6 \\
& District of Gombak & 35 & 26.1 \\
& District of Klang & 20 & 14.9 \\
& District of Sepang & 10 & 7.4 \\
& Total & $\mathbf{1 3 4}$ & $\mathbf{1 0 0 . 0}$ \\
Size & & & \\
(i.e. capacity for & Less than 100 & 8 & 6.0 \\
congregations) & 101-500 & 39 & 29.1 \\
& 501-1,000 & 41 & 30.6 \\
& 1,001-2,000 & 14 & 10.4 \\
& 2,001-3,000 & 17 & 12.7 \\
& Above 3,001 & 15 & 11.2 \\
& Total & $\mathbf{1 3 4}$ & $\mathbf{1 0 0 . 0}$ \\
& & & \\
Economic activities & Investment accounts in local banks & $72 / 134$ & 53.7 \\
& Mosque cooperative & $16 / 134$ & 11.9 \\
& Rental of shop lots & $51 / 134$ & 38.1 \\
& Rental of homestay/ house & $40 / 134$ & 29.9 \\
& Rental of seminar rooms/ & $55 / 134$ & 41.0 \\
& multi-purpose hall & & 32.8 \\
& Rental of telecommunication tower & $44 / 134$ & 6.7 \\
\hline site & & \\
& Agriculture project/ farms & $9 / 134$ & \\
\hline
\end{tabular}

Based on the survey, there are also important evidence found where the major economic activities are related to the rental activities of mosque's assets. Half of the mosques has an investment account at local banks (72/134 or 53.7\%) for the purposes of investing cash for some financial return. The other major activities are rental based activity of the mosque's assets such as shop lots, homestay, seminar rooms, multi-purposes hall and site for telecommunication 
tower. The least popular activities is the agriculture project and farming (9/134 or 6.7\%). Interestingly from the findings, there are certain mosques are gradually promotes mosque's cooperative within their compound. It is the strategic measures in promoting attractive funds investment and inclusive participation of local Muslims with mosque economic project.

Table 2 shows the results of reliability test of the main measurement factors understudy. Cronbach's Alpha test recorded measurement value in between 0.665 and 0.900 for all factors. Therefore, it indicates that all items were strongly correlated to one another and acceptable for the study (Hair et al., 2007). Further, the Composite Reliability (CR) and Average Variance Extracted (AVE) test shows the reliability of internal consistency with the values of more than 0.50 . Thus, it was consider excellently predicted.

Table 2. Results of Cronbach's Alpha, composite reliability and average variance extracted

\begin{tabular}{lccc}
\hline Factor & $\begin{array}{c}\text { Cronbach's } \\
\text { Alpha }(\mathbf{C A})\end{array}$ & $\begin{array}{c}\text { Composite } \\
\text { Reliability (CR) }\end{array}$ & $\begin{array}{c}\text { Average Variance } \\
\text { Extracted (AVE) }\end{array}$ \\
\hline Innovation & 0.776 & 0.871 & 0.694 \\
Pro-activeness & 0.834 & 0.842 & 0.670 \\
Risk taking & 0.900 & 0.930 & 0.769 \\
Financial performance & 0.665 & 0.765 & 0.482 \\
Non-financial & 0.776 & 0.871 & 0.694 \\
performance & & & \\
\hline
\end{tabular}

Table 3 indicates the results of the convergent and discriminant validity analysis in measuring the structural model. Results shows all variance inflation factor (VIF) values are less than 10. Thus suggested there are no indication of collinearity between variables as stated by Hair et al., (2007).

Table 3. Results of convergent and discriminant validity analysis

\begin{tabular}{lcccccc}
\hline \multicolumn{1}{c}{ Factors } & $\mathbf{1}$ & $\mathbf{2}$ & $\mathbf{3}$ & $\mathbf{4}$ & $\mathbf{5}$ & $\mathbf{6}$ \\
\hline 1. Innovativeness & 0.833 & & & & & \\
2. Pro-activeness & 0.670 & 0.818 & & & & \\
3. Risk taking & 0.496 & 0.521 & 0.877 & & & \\
4. Strategic orientation & 0.739 & 0.746 & 0.581 & 0.764 & & \\
5. Financial performance & 0.023 & 0.016 & 0.093 & 0.002 & 0.694 & \\
6. Non-financial performance & 0.534 & 0.671 & 0.495 & 0.739 & 0.022 & 0.833 \\
\hline
\end{tabular}

Table 4 display the results of hypothesis testing for all dependent and independent variables as well as their expected relationship. The results shows that all elements had positive relationship, except for strategic orientation and financial performance $(\beta=-0.0097)$. The findings confirmed the current assumption that the mosques objectives in pursuing economic activities is not directly based on the purposes of gaining financial return as seemed occurred amongst the profit-making organization. The main purposes of conducting economic activities is mostly categorise as the social business practices as mentioned by Omar, Hussin and Muhammad (2015). Specifically, Table 4 indicates the summary of findings that there is positive and significant relationship exist in between the pro-activeness construct as the predictive factors for mosque strategic orientation $(\beta=0.290 ; t=2.728 ; p=0.007)$ and the mosques strategic orientation and non-financial performance $(\beta=0.657 ; \mathrm{t}=6.790 ; \mathrm{p}=0.097)$. The results support the strategic orientation theory of Lumpkin and Dess (1996) where SO had certain interaction between organization's strategy and the business or operational performance within the organization. 
Table 4. Hypothesis testing results

\begin{tabular}{lccccl}
\hline \multicolumn{1}{c}{ Hypothesis } & Beta & t-test & p-value & VIF & $\begin{array}{c}\text { Empirical } \\
\text { Evidence }\end{array}$ \\
\hline Innovation > Strategic Orientation & 0.085 & 1.206 & 0.228 & 2.103 & Not supported \\
\hline Risk taking > Strategic Orientation & 0.119 & 1.206 & 0.228 & 1.210 & Not supported \\
\hline Pro-activeness > Strategic Orientation & 0.290 & 2.728 & $0.007^{* *}$ & 2.580 & Supported \\
\hline SO > FP & -0.097 & 0.669 & 0.146 & 1.388 & Not supported \\
\hline SO > NFP & 0.657 & 6.790 & $0.097^{* * *}$ & 1.388 & Supported \\
\hline R Square & \multicolumn{5}{c}{0.934} \\
\hline Adjusted R Square & \multicolumn{7}{c}{0.930} \\
\hline
\end{tabular}

Significant level: $* * *=0.010 ; * *=0.050, *=0.10$

\section{Discussion}

The study brings new contribution to the existing literature. The result revealed insights into how strategic orientation influence the religion based organization performance. As Baba (2015) suggest, that non-economic performance is the primary organizational feature that drives the non-profit organizations, this study is also support the evidence. Within the context of mosques, we found the same evidence where the strategic orientation exists in determining mosques non-financial performance as compared to financial performance. Secondly, as the strategic orientation emphasis on three areas of estimations, the pro-activeness dimension is the only area that support the strategy of the mosques management committee in pursuing their economic activities. Leaders with certain forward-looking effort in such a way promoting new market offerings to the community or congregation members is bring in some advantages to the mosques as stated by Omar, Hussin and Muhammad (2017). At the current stage, mosque's leaders whom are actively explore the new source of income generating activities by utilising their existing assets are mostly fruitful since these religion organizations is mainly supported by all Muslims. Therefore, various economic based activities such as mosques cooperative, rental of shop-lots or homestay and other rental activities of mosque's facilities (seminar room, multi-purpose hall, telecommunication tower site and others) will ensure better engagement within mosque and the community.

The practical recommendation is that mosques leaders should be empowered by the State Religious Department and authorities to pursue some strategic economic activities with clear guidelines and policy. They should be educate with various business management knowledge about idea generation, business risk evaluation, marketing strategies, human resource management, accounting and financial reporting as well as the basic investment analysis. Certain percentage of mosques assets, capital and funds should be allocate into such a productive economic based activities for the betterment of Muslims community within the mosques vicinity. Promotional activities must be properly plan and execute to create further awareness of the community members about mosques economic initiatives. Hence, it will probably increase the value of sales and revenue for those activities. Future studies are recommended in this area as this study offers an initial exploration into this understudy of strategic orientation within the scope of religion based organization.

\section{References}

Al-Ansaari, Y., Bederr, K., \& Chen, C. (2015). Strategic orientation and business performance: an empirical study in the UAE context. Management Decision, 53(10), 2287-2302.

Aloulou, W.J. (2019). Impacts of strategic orientations on new product development and firm performances: insights from Saudi industrial firm. European Journal of Innovation Management, 22(2), 257-280.

Baba, Y. (2015). Does learning orientation matter for nonprofit organization performance? Empirical evidence from Ghana. Leadership \& Organization Development Journal, 36(3), 234-252.

Balodi, K.C. (2014). Strategic orientation and organizational forms: an integrative framework. European Business Review, 26(2), 188-203.

Basbeth, F., Ramli, A., Razik, M.A., Zain, R.M., \& Nawi, N.C. (2019). The role of multi dimensional EO in the competitive strategy - performance link. Research in World Economy, 10(2), Special Issue, 20-25.

Budiman, M.A., \& Sandewa, M.M. (2017). Assessing the roles of mosques in enhancing the Islamic economic practices. Advances in Social Science, Education and Humanities Research, 126, 95-99. 
Chatzoglou, P., Chatzoudes, D., Sarigiannidis, L., \& Theriou, G. (2018). The role of firm-specific factors in the strategy-performance relationship: Revisiting the resource-based view of the firm and the VRIO framework. Management Research Review, 41(1), 46-73.

Cossiga, G.A. (2018). Signals from the World of Economics. The Price Constant and the Democratic Issue. International Journal of Social and Administrative Sciences, 3(1), 1-21.

Gamba, F.J. (2017). Social capital in selected business associations of food processing SMEs in Tanzania and Rwanda: A synthetic-based approach. International Journal of Asian Social Science, 7(1), 63-84.

Hair, J., Money, A., Samouel, P., \& Page, M. (2007). Research Methods for Business. New York: John Wiley \& Sons.

Hussain, H.I., Grabara, J., Razimi, M.S.A., \& Sharif, S.P. (2019). Sustainability of Leverage Levels in Response to Shocks in Equity Prices: Islamic Finance as a Socially Responsible Investment. Sustainability, 11(12), 3260.

Jaafar, A., Habidin, N.F., Hussin, M.Y.M., Zakaria, H., \& Hamid, A.A. (2013). A proposed model for strategic management (SM) and mosque performance (MP) in mosque management. BEST: International Journal of Management, Information Technology and Engineering, 1(3), 29-36.

Jebali, L., \& Hmedi, S. (2015). Basel accord and banking competitivity. Journal of Asian Business Strategy, 5(12), 252-258.

Jokakuu, M.A. (2018). Assessing the Effectiveness of Management Consultancy in Operations of Construction Firms: A Case of Willy Enterprises Ltd in Arusha Tanzania. Asian Business Research Journal, 3, 26-32.

Lumpkin, G.T., \& Dess, G.G. (1996). Clarifying the entrepreneurial orientation construct and linking it to performance. Academy of Management Review, 21, 135-172.

Mansor, N.H., \& Ilias, A. (2013). Goods and services tax (GST): A new tax reform in Malaysia. International Journal of Economics Business and Management Studies, 2(1), 12-19.

Masood, O., Tvaronavičienė, M., \& Javaria, K. (2019). Impact of oil prices on stock return: evidence from G7 countries. Insights into Regional Development, 1(2), 129-137.

Miller, D. (1983). The correlates of entrepreneurship in three types of firms. Management Science, 29, 770-791.

Muhammad, F., Hussin, M.Y.M., Razak, A.R., \& Hadi, F.S.A., (2014). Persepsi masyarakat Islam terhadap idea penjanaan dana masjid: kajian di Perak. Sains Humanika, 2(1), 101-106.

Omar, A.R.C., Hussin, M.Y.M., \& Muhammad, F. (2015). Social entrepreneurship practices among mosques in Selangor. In Ibrahim, M.F. (Ed.), Amalan Keusahawanan Islam, Konsep dan Isu Perlaksanaan (pp. 171-184). Kuala Lumpur: Pusat Pungutan Zakat, Majlis Agama Islam Wilayah Persekutuan.

Omar, A.R.C., Hussin, M.Y.M., \& Muhammad, F. (2017). Strategic orientation and mosque economic activites. Journal of Global Business and Social Entrepreneurship, 3(9), 25-31.

Rahman, M.F.A., Mastuki, N., \& Yusof, S.N.S. (2015). Performance measurement model of mosques. Procedia Economics and Finance, 31, 26-35.

Razak, A.A., Hussin, M.Y.M, Muhammad, F., \& Mahjom, N. (2014). Economic significance of mosque institution in Perak State, Malaysia. Kyoto Bulletin of Islamic Studies, 7, 98-109.

Sen, D., Bingol, S., \& Vayvay, O. (2017). Strategic enterprise management for innovative companies: The last decade of the balanced scorecard. International Journal of Asian Social Science, 7(1), 97-109.

Sharif, I., Wahab, S.R.A., \& Sarip, A. (2017). Psychological Contract Breach and Feelings of Violation: Moderating role of Age-Related Difference. International Journal of Asian Social Science, 7(1), 85-96.

Sriyana, J. (2019). What drives economic growth sustainability? Evidence from Indonesia. Entrepreneurship and Sustainability Issues, 7(2), 906-918.

Storey, C., \& Hughes, M. (2013). The relative impact of culture, strategic orientation and capability on new service development performance. European Journal of Marketing, 47(5/6), 833-856.

Yadav, S.K., Tripathi, V., \& Goel, G. (2019). Modelling strategic orientation dimensions and performance of small and medium enterprises: An application of interpretative structural modelling. Journal of Modelling in Management, 14(3), 754-772.

Yasoa, M.R., Ghazali, M.S., Alwi, M.A.M., Rahman, A.H.A., Abdullah, S.S., Abdullah, A.R., ... Yaacob, M.R. (2019). Fund management - an exploratory case study of several mosques in Kelantan. Research in World Economy, 10(2), Special Issue, 53-57. 